\title{
Rational efficiency in agro-industrial process with cold chain: Thermodynamic and exergoeconomic measurement
}

\author{
Eficiencia racional en un proceso agroindustrial con cadena de frío: \\ Medición termodinámica y exergoeconómica
}

\section{Eficiência racional em um processo agroindustrial com corrente de frio: Medição termodinâmica e exergoeconômica}

Fecha de recepción: 6 de octubre de 2017

Fecha de aprobación: 19 de diciembre de 2017
Víctor Hugo Cely-Niño*

Héctor Cifuentes-Aya*

Gemma Cervantes Torre-Marín ${ }^{* * *}$

\begin{abstract}
The cold chain is the succession of links such as pre-cooling, refrigeration, freezing, and refrigerated transport. The physical variables of the heat transfer process are temperature control, relative humidity, dew point, and cooling surface. This paper aims at highlighting the use of thermodynamic tools such as exergy, anergy and entropy to measure rational efficiency in the different equipment and flows of a thermal process, through a transversal methodology that quantifies efficiencies in a relative, absolute, and comparative way. This study focused on the production structure of the agro-industrial cold chain by steam compression (refrigerant R404A), for the meat processing in channel, in the "Rastro Frigorífico Servicios Integrales del Bajío-TIF 333" in the city of LeonGuanajuato, central region of Mexico. The results from the literature allowed to classify the critical points of greater exergy destruction, and the unproductive teams responsible for inefficiencies and residues production, which impact the hidden cost structure of the process, and affect negatively the process sustainability. This work integrates the thermoeconomic and productivity concepts that direct the nonlinear learning of thermodynamic science, relevant in the formation of an engineer.
\end{abstract}

Keywords: cold chain; hidden costs; productivity efficiency; thermal irreversibility.

\section{Resumen}

La cadena de frío es una sucesión de eslabones, como preenfriamiento, refrigeración, congelación y transporte refrigerado. Las variables físicas del proceso de transferencia de calor son: temperatura, humedad relativa, punto de rocío y superficie de refrigeración. El propósito del artículo es visibilizar el uso de herramientas termodinámicas, como exergía, anergía y entropía, para medir la eficiencia racional en los diferentes equipos y flujos de un proceso térmico, mediante una metodología transversal para cuantificar las eficiencias en forma relativa, comparada y

* Ph. D. (c) Universidad Nacional de Colombia (Bogotá-Distrito Capital, Colombia). vhcelyn@unal.edu.co. ORCID: 0000-0003-3163-1123. ** Ph. D. Universidad Nacional de Colombia (Bogotá-Distrito Capital, Colombia).hcifuentes@unal.edu.co. ORCID: 0000-0003-3912-5284.

*** Ph. D. Universidad de la Salle Bajío (Guanajuato, México). gemmacervantes@ugto.mx. ORCID: 0000-0003-1713-3005. 
absoluta. Se partió de una estructura productiva de cadena de frío agroindustrial por compresión de vapor (con refrigerante R404A), para el procesamiento de carne en canal, en el "Rastro Frigorífico Servicios Integrales del Bajío-TIF 333", en la ciudad de León-Guanajuato, centro de México. Los resultados obtenidos y contrastados permiten clasificar los puntos críticos de mayor destrucción de exergía y los equipos improductivos responsables de ineficiencias y producción de residuos, con incidencia en la estructura de costos ocultos del proceso e impacto negativo sobre la sostenibilidad del proceso.

Este trabajo integra conceptos como termoeconomía y productividad, que direccionan el aprendizaje no lineal de la ciencia termodinámica, relevante en la formación del ingeniero.

Palabras clave: cadena de frío; costo oculto; eficiencia productiva; irreversibilidad térmica.

\section{Resumo}

A corrente de frio é uma sucessão de elos, como pré-resfriamento, refrigeração, congelação e transporte refrigerado. As variáveis físicas do processo de transferência de calor são: temperatura, humidade relativa, ponto de condensação e superfície de refrigeração. O propósito do artigo é visibilizar o uso de ferramentas termodinâmicas, como exergia, anergia e entropia, para medir a eficiência racional nos diferentes equipamentos e fluxos de um processo térmico, mediante uma metodologia transversal para quantificar as eficiências em forma relativa, comparada e absoluta. Partiu-se de uma estrutura produtiva de corrente de frio agroindustrial por compressão de vapor (com refrigerante R404A), para o processamento de carne em carcaça, no "Rastro Frigorífico Servicios Integrales del Bajío-TIF 333", na cidade de León-Guanajuato, centro do México. Os resultados obtidos e contrastados permitem classificar os pontos críticos de maior destruição de exergia e os equipamentos improdutivos responsáveis de ineficiências e produção de resíduos, com incidência na estrutura de custos ocultos do processo e impacto negativo sobre a sustentabilidade do processo.

Este trabalho integra conceitos como termoeconomia e produtividade, que direcionam a aprendizagem não lineal da ciência termodinâmica, relevante na formação do engenheiro.

Palavras chave: corrente de frio; custo oculto; eficiência produtiva; irreversibilidade térmica.

\section{Para citar este artículo:}

V. H. Cely-Niño, H. Cifuentes-Aya, and G. C. Torre-Marín, "Rational efficiency in agro-industrial process with cold chain: Thermodynamic and exergoeconomic measurement," Revista Facultad de Ingeniería, vol. 27 (47), pp. 39-49, Jan. 2018. 


\section{INTRODUCTION}

The relationships among entropy, exergy and anergy (irreversibility) are immersed in the information and organization of dynamic cycles in finite industrial production. The process concept refers to a thermodynamic system, which interacts with its environment and depends on its limits or boundaries, the aggregation level of production (resources, components and relations), and its information, to measure the efficiency of the system and the productivity of the processes.

Exergy is applied to the analysis of industrial processes in steady state. The process generates functional products, residues, and unwanted products. Exergy is the criterion to determine the efficiency through the exergy destroyed in each stage, generated by irreversibilities (residues), which correspond to the process inefficiency [1]. Exergy provides criteria for developing theories, models and approximations based on thermodynamics, which can increase predictive and analytical power in basic and environmental sciences, and in ecology and industrial ecology [2].

The Gouy-Stodola Substitution Theorem explains that the destroyed exergy is proportional to the generated entropy, and that the irreversibilities generate entropy and, therefore, destroy exergy. A minimum generation of entropy indicates high efficiency. The destroyed exergy is quantified within the limits of a complex system, and it is not possible to obtain the dissipated out of the process. When no exergy is destroyed, the process is internally reversible, but not necessarily totally reversible [1]. The rational exergetic efficiency, which allows evaluating the performance of the system, is the relation between the used exergy flow with respect to the input, and can be obtained by applying the lowering principle of the incoming exergy.

The Doctoral Dissertation "Measurement of productivity in processes that integrate cold chain, based on assessments of exergoeconomics and ecoefficiency", developed in the slaughter plant TIF 333 of León-Guanajuato State (Mexico), determined the incidence of exergy and anergy in the rational efficiency of the cold chain in processes of agroindustrial transformation. In this dissertation, the exergetic losses of the processes were divided into two parts: one internal due to the destruction of exergy caused by the irreversibility of the system, and one external due to the degradation of the low entropy resources (fossil fuel or materials), to turn them into "resources" of high entropy that are discarded as residues.

\section{LITERATURE REVIEW}

\section{A. Thermodynamic background}

The concept of exergy was proposed in 1956 by Zorant Rant, and was developed between 1964 and 1967 by Rabek, Szargut \& Petela, Baehr, Brodyanski, Fratscher, Elsner, Nitsch, Bergmann \& Schmidt. Since the formalization of the exergy concept, the development of exergy analysis can be differentiated into three periods [2]. During the first period (19711984), which corresponds to "exergy in chemical processes", the calculation of exergetic efficiency was introduced to the process technical efficiency; the second period (1989-1995) was "economic optimization and thermodynamic methods"; and in the third period (1996-2016), "exergy of society", the equilibrium thermodynamics and exergy extended to form an interdisciplinary approach to wastewater treatment, biofuels production, and second generation biodiesel, which are important approximations to the economic, environmental and ecological dimensions, along with the framework of sustainable business development.

\section{B. Exergoeconomic evolution}

From the technical efficiency and productivity standpoint, the exergetic analysis measures the system's capacity to bring about a productive change, because it allows the reassignment of resources, costs and performance. The interdisciplinary relationship between exergy and economics was developed at the University of Zaragoza [3]. In the last twenty years, exergoeconomics has gone through different methodologies: Average Cost (AVCO), Exergy Cost Calculation (EXCO), Specific Exergy Cost (SPECO), Functional Analysis (TFA), and Functional Analysis Engineering (EPT) [4].

In [5], four sustainability elements were articulated to the industrial debate: social, economic, environmental, and technological. The most important relationship of flows reported in the literature specifies the schematic 
representation of the exergy flowing between the society and the environment [6]. Furthermore, Suresh et al. [7] identified that hidden costs imply impacts of the industrial production on the environment and society, which in monetary terms form the core of research projects, with the methodology called "4E". In a more integrating context, Khoshgoftar et al. [8] applied the new discipline exergoeconomic as a specific fusion between the exergy analysis and its endogenous economic valuation, developed through indicators.

\section{EXERGOECONOMIC RELATIONAL FRAMEWORK}

The second principle of thermodynamics states that the incoming exergy in a system that performs a natural process will always be greater than the resulting exergy, fulfilling that (incoming exergy) (outgoing exergy) $=$ Irreversibility $(\mathrm{I})>0$. In industrial processes, the purpose is to transform Resources $(\mathrm{F})$ into Products $(\mathrm{P})$, without losing energy, although you always lose quality. The real processes are irreversible and they follow $(\mathrm{F})-(\mathrm{P})=\mathrm{I}>0$, which explains that the exergy needed to obtain a product will always be greater than or equal to the exergy it contains.

\section{A. Conceptual bases of measurement in a thermal system}

A system is a complex entity formed by a set of elements (a machine, living beings or an economic system) that are its basic components, and by the relationships between them and their environment. The aggregation level provides a breakup of the process' total irreversibility into its components, while the efficiency $(\eta)$ indicates the exergetic performance of the equipment where the irreversibilities are located.

The physical structure of a system, plus the definition of the productive purpose of each equipment constitute the productive structure of a thermal system, which is vital for the exergoeconomic analysis and supports the integrated measurement of rational efficiency. In the exergoeconomic conceptual framework, the cost of the product includes the cost of both the internal and the external (residues) irreversibilities.

\section{B. Residues formation process}

According to their nature, three types of unwanted products are considered: derivative by-products (D), losses $(\mathrm{L})$ and residues $(\mathrm{R})$. The productive structure of a process has $n$ components (plus the component 0 that corresponds to the environment $\mathrm{M}$ ) interconnected by flows that characterize its exergy. An exergy flow from component $\mathrm{I}$ to component $\mathrm{J}$ is represented by $\mathrm{E}_{\mathrm{ij}}$. When it comes to specific exergy $(\mathrm{J} / \mathrm{kg})$, it is noted with $\dot{\mathrm{E}}_{\mathrm{ij}}$. Each component consumes resources from others or from $\mathrm{M}$, to produce $(\mathrm{P})$ effects on other products or on $\mathrm{M}$. Consequently,

$$
\mathrm{F}_{\mathrm{i}}=\sum_{i=0}^{n} \mathrm{E}_{\mathrm{ij}}(1) ; \quad \mathrm{P}_{\mathrm{i}}=\sum_{j=0}^{n} \mathrm{E}_{\mathrm{ij}}(2)
$$

The product $(\mathrm{P})$ has two different destinies according to (3): a flow $\left(\mathrm{P}_{\mathrm{A}}\right)$ that could be a resource for another product, and another flow $\left(\mathrm{P}_{\mathrm{R}}\right)$ that is not used by any other component, or is part of the final product, so it is a residue (Fig. 1).

$$
\mathrm{P}=\mathrm{P}_{\mathrm{A}}+\mathrm{P}_{\mathrm{R}}
$$

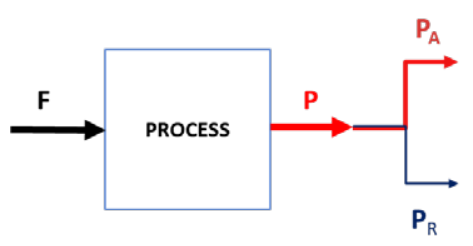

Fig. 1. Useful product and residue.

It builds the thermodynamic function that enables the evaluation of hidden costs, in terms of the resources exergy that the system requires [3].

The exergetic cost of a flow is $E^{*}$; the exergetic unit cost of flow $\mathrm{E}$ is denoted as $\mathrm{k}^{*}$; consequently, the exergetic cost of a flow (component) is

$$
\mathrm{E}^{*}=\mathrm{k}^{*} \mathrm{E}
$$

On the other hand, the exergetic costs of resources, products and residues are denoted as follows: $\mathrm{F}^{*}=\mathrm{k}^{*}$ $\mathrm{F} ; \mathrm{p}^{*}=\mathrm{k}^{*} \mathrm{p} ; \mathrm{R}^{*}=\mathrm{k}^{*} \mathrm{R}$. In case of specific exergy,

$$
\dot{\mathrm{E}}^{*}=\mathrm{k}^{*} \dot{\mathrm{E}}
$$

Three propositions are considered to measure rational efficiency: 1) the exergetic cost of all flows depends 
on the costs of input resources, thus, the cost of input flows to the system will be equal to its exergy, its unitary exergetic cost is one; 2) all costs generated in the production process must be included in the final cost of the products, and the cost of the loss flows is null, that is, $\mathrm{F}^{*}=\Sigma \mathrm{P}^{*}$; and 3 ) if several products leave the same equipment, the training process will be the same and will have the same exergetic unitary cost.

The allocation of the exergetic cost is proportional to the exergy the flows contain, and the exergetic cost of the residue is added to the equipment where it originates. The exergoeconomic cost $\Pi(\$ / \mathrm{kg})$ is the product of the unit cost $C(\$ / J)$, multiplied by the flow of specific exergy $(\dot{\mathrm{E}})$, in $(\mathrm{J} / \mathrm{kg})$. Therefore,

$$
\Pi=\mathrm{c} \dot{\mathrm{E}}
$$

\section{Quantifying the cost of residues}

The exergetic cost of residues $\left(\mathrm{R}^{*}\right)$ can be produced both in the equipment in which the flow is produced and along a chain of flows and equipment of the production process. The exergoeconomic rule states that the cost of the resources is allocated to the useful product.

$$
F^{*}=P_{A}^{*}
$$

Combining equations (1) and (7) result in equation (8):

$$
k_{P}{ }^{*} P=k_{P}{ }^{*} P_{A}+k_{P}{ }^{*} P_{R}
$$

Denominating $\mathrm{R}^{*}$ as the cost of the resources that have been used to generate the flow of the residual $P_{R}$, the equation (7) becomes equation (9):

$$
P^{*}=P_{A}^{*}+R^{*}
$$

Thus, the total cost of producing the generic component $(\mathrm{P})$ is given by $(10)$.

$$
F^{*}+R^{*}=P^{*}
$$

Figure 2 shows the residue formation chain. The mitigation/compensation $(\mathrm{R})$ resource flow is the resource 0 described in equations (3-8), increasing the cost structure.

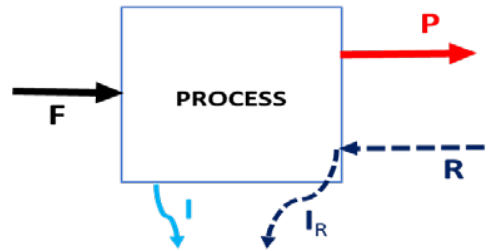

Fig. 2. Balance of exergy and residues.

The cost of the exergetic operation of the equipment (CEX) is the product of the resource exergetic unit cost and the flow of the irreversibilities, explained by (11).

$$
\mathrm{CE}_{\mathrm{X}}=\mathrm{k}_{\mathrm{F}}^{*} \mathrm{I}
$$

The cost of the equipment operation (CO) is the product of the unit cost of the resource by the flow of the irreversibilities (12).

$$
\mathrm{CO}=\mathrm{C}_{\mathrm{F}} \dot{\mathrm{I}}
$$

\section{Mechanical compression refrigeration circuit}

The conceptual operation of the refrigeration thermal machine is a thermal cycle of Heating, Ventilating, and Air Conditioning-Refrigeration (HVAC-R) (Fig. 3 ). The real cycle develops four ideal thermodynamic stages: two isothermal and two isentropic in León-GT. These stages result from the interaction of the four devices and the refrigerant fluid that extracts heat from the box (cooling chamber). In the ideal cycle, exergy is not destroyed [9].

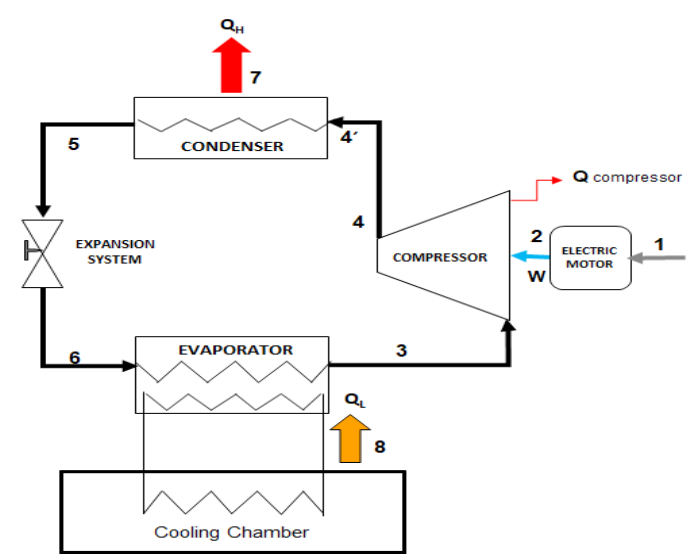

Fig. 3. Freezing system by steam compression [1]. 
The exergy balance must be described in a set of equations and balances exergetics to calculate performance; this will allow to quantify the exergy destroyed in each device and the discharge line of the HVAC-R refrigeration cycle. The HVAC-R refrigeration cycle is added as a fictitious equipment to the exergy balance, because the greater anergy and irreversibility contribution are located in the compressor, due to the discharge level $(\Delta \mathrm{P} / \mathrm{L})$ and the heat dissipation $\dot{Q}_{c o m p}[10]$. The balance sheets are as follows:

- Balance in compressor: between points 3 and 4 (Fig. $3)$.

$$
\dot{E} x_{d, c o m p}=\dot{W}+\dot{m} \psi_{3}-\dot{m} \psi_{4}-\left(1-\frac{T_{0}}{T_{w, c o m p}}\right) \dot{Q}_{c o m p}
$$

Where $T_{w}$, comp is the temperature at the compression wall limit, and corresponds to the average obtained through the thermometer-infrared sensor (without contact).

- Balance in the condenser: between points $4^{\prime}$ and 5 (Fig. 3).

$$
\dot{E} x_{d, \text { cond }}=\dot{m} \psi_{4^{\prime}}-\dot{m} \psi_{5}-\dot{\boldsymbol{Q}}_{\boldsymbol{H}}\left(1-T_{0} / \boldsymbol{T}_{\boldsymbol{H}}\right)
$$

Where $\mathrm{Q}_{\mathrm{H}}=\mathrm{Q}_{7}$ is the heat expelled to the environment, and $\mathrm{T}_{\mathrm{H}}$ is the temperature $\mathrm{T}_{4}{ }^{\prime}$. The heat balance in the condenser is $\mathrm{Q}_{4}{ }^{\prime}=\mathrm{Q}_{5}+\mathrm{Q}_{7}$.

- Balance in the discharge line of compressor: between points 4 and 4' (Fig. 3).

$$
\dot{E} x_{d, l d}=\dot{m} \psi_{4}-\dot{m} \psi_{4^{\prime}}-\left(1-\frac{T_{0}}{T_{w, l d}}\right) \dot{Q}_{l d}
$$

Where $T_{\mathrm{w}, \mathrm{ld}}$ corresponds to the pipe wall. This equipment (unreal) is added to the system to better estimate the exergy destroyed in the cycle.

- Balance in the valve system: between points 5 and 6 (Fig.3).

$$
\dot{E} x_{d, \exp }=\dot{m} \psi_{5}-\dot{m} \psi_{6}
$$

- Balance in the evaporator: between points 6 and 3 (Fig. 3).

The destruction of exergy is

$\dot{E} x_{d, \text { evap }}=\dot{m} \psi_{6}-\dot{m} \psi_{3}+\dot{Q}_{L}\left(1-T_{0} / T_{L}\right)$

Where $\mathrm{Q}_{\mathrm{L}}=\mathrm{Q}_{8}$ is the heat flux extracted from the chamber and transferred to the refrigerant, and $\mathrm{T}_{\mathrm{L}}$ corresponds to the temperature $\mathrm{T}_{8}$. The heat balance in the evaporator is $\mathrm{Q}_{3}=\mathrm{Q}_{6}+\mathrm{Q}_{8}$

The sum of the destructions in equations (13-17) result in the total destruction.

$$
E x_{\text {destruida total }}=\dot{E} x_{d, \text { comp }}+\dot{E} x_{d, l d}+\dot{E} x_{d, \text { cond }}+\dot{E} x_{d, \text { exp }}+\dot{E} x_{d, \text { evap }}
$$

The exergetic efficiency of the refrigeration cycle is

$$
\eta_{E x}=1-\frac{E x_{d, t o t a l}}{\dot{W}}
$$

The destruction rate $\left(\dot{E} x_{\text {entrada }}-\dot{E} x_{\text {salida }}\right)$ is the exergy consumption, due to the irreversibilities within the device or the difference between inputs and outputs in steady state.

The index of the process exergetic improvement (potential of improvement) is

$$
\dot{I}=\left(1-\eta_{E x}\right)\left(\dot{E} x_{\text {entrada }}-\dot{E} x_{\text {salida }}\right)=\left(1-\eta_{E x}\right)\left(\dot{E} x_{\text {destruida total }}\right)
$$

\section{Methodology}

This study used a mixed methodological approach of descriptive type, particularly the analysis- synthesis, based on the analysis of exergetic and exergoeconomics. The evaluation of thermal inefficiencies (irreversibilities), accessory equipment, motors, fans, condensers, and evaporators is conducted 
through sensitivity, fault and defect (leakage) analyses $[11,12]$.

We applied five methodological steps: (a) determination of variables, limits and aggregation levels; (b) thermodynamic analysis of parameters and engineering operation; (c) data analysis (response functions); (d) construction of Grassman diagrams for exergetic efficiencies; and (e) calculation of rational efficiency, in equipment, currents and residues.

The environmental conditions (dead state) of the slaughter plant were the following: temperature $27^{\circ} \mathrm{C}$, relative humidity $27 \%$, elevation 1815 meters above sea level, and pressure $810 \mathrm{hPa}$. The refrigeration system is the production of cold by steam compression, with refrigerant R404A. The physicochemical data (temperature, pressure, and humidity) were captured with data-logger (MSR), hygrometers, infrared temperature sensor, and vacuum thermometers (bourdon type) coupled to the condenser.

\section{RESULTS}

\section{A. Analysis of the agro-industrial process}

The agro-industrial process in the slaughter plant of "Rastro de León" consists of self-propelled, hoisting, bleeding, flagellation, washing in a chiller, carcass processing (eviscerated, boned and quarting), classification, packing, and thermal conservation. The animal in rigor mortis was initially cooled off in a liquid cooler with chiller worm screw liquid that operates from $6-8^{\circ} \mathrm{C}$. The capacity of the trail for conservation consists of four transitional chambers of $130 \mathrm{~m}^{3}$ for internal irrigation; the load entered at $25{ }^{\circ} \mathrm{C}$ and then was thermally collided with sprinkler water $\left(6-9^{\circ} \mathrm{C}\right)$ to reach an average of $15^{\circ} \mathrm{C}$. The final product was frozen in a superflex camera, with a capacity of 900 $\mathrm{m}^{3}$; each camera can store up to $400-500$ pigs of 150 $\mathrm{kg}$ or $150-200$ cattle of $400 \mathrm{~kg}$. The residence time in the chamber was 24 hours for pigs and 36 hours for cattle.

The refrigerant fluid used for the compression cycle was R404A. There were three ultra-freezing chambers, of $360 \mathrm{~m}^{3}, 150 \mathrm{~m}^{3}, 100 \mathrm{~m}^{3}$ and $50 \mathrm{~m}^{3}$. The thermal power given by the manufacturer was $15 \mathrm{~kW}, 11 \mathrm{~kW}$, and $7.5 \mathrm{~kW}$. The freezing temperature was $-25^{\circ} \mathrm{C}$.

\section{B. Productive structure}

The productive structure was built by generating energy balances around the five equipment and the eight currents of the HVCA-R process in the cold chain (Fig. 4).

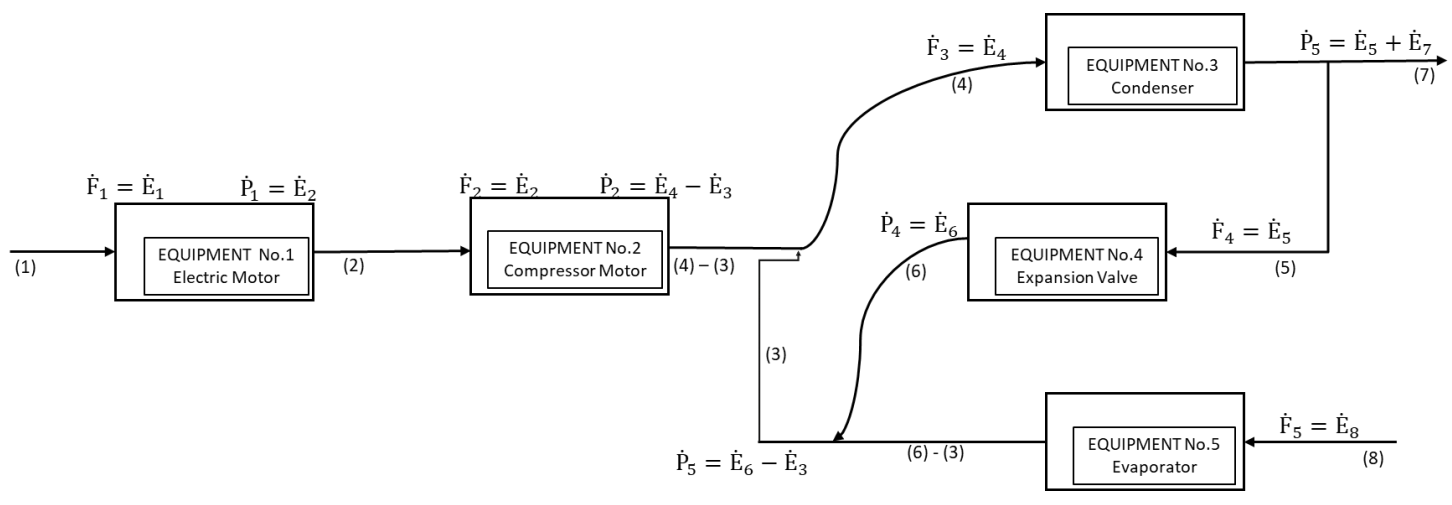

Fig. 4. Production structure of the compression freezing system.

\section{Parameters obtained}

We measured the changes in temperature in the freezing chambers for 12 continuous hours, and obtained average operating temperatures $\left(\mathrm{T}_{\mathrm{L}}\right)$ for the superflex camera $\left(-4{ }^{\circ} \mathrm{C}\right)$, chamber freezing $\left(-16^{\circ} \mathrm{C}\right)$, and ultra-freezing $\left(-25^{\circ} \mathrm{C}\right)$ (Fig. 5). 


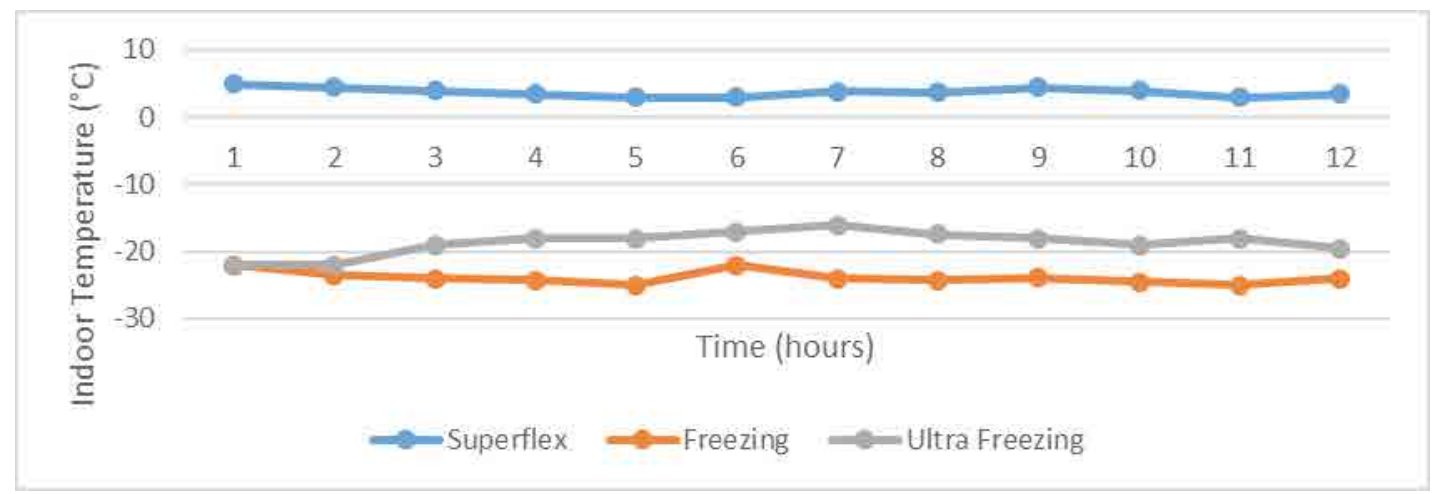

Fig. 5. Thermography in storage chambers.

\section{Rational efficient calculus}

Based on Table 4 and equations (11-12), we calculated the amount of resources, products, residues, irreversibilities, exergetic efficiencies, operating exergetic costs, and operating exergoeconomic costs for each equipment and current (flow) of the refrigeration system determined in the production structure. In addition, we obtained the exergetic efficiency of each equipment and current by applying the balance equations (13-19) and the $2^{\text {nd }}$ law.

\section{TABLE 1}

RESOURCES, PRODUCTS, RESIDUES, IRREVERSIBILITY, EFFICIENCY (EQUIPMENT)

\begin{tabular}{|l|c|c|c|c|c|}
\hline \multicolumn{1}{|c|}{ Equipment } & $\dot{\mathrm{F}}(\mathrm{kW})$ & $\dot{\mathrm{P}}(\mathrm{kW})$ & $\dot{\mathrm{R}}(\mathrm{kW})$ & $\dot{\mathrm{I}}(\mathrm{kW})$ & $\eta(\%)$ \\
\hline No. 1. Electric Motor & 5.5168 & 4.6341 & 0 & 0.8827 & 84.0 \\
\hline No. 2. Compressor & 4.6341 & 4.1197 & 0 & 0.5144 & 89.0 \\
\hline Fictitious: Discharge Line & 4.6341 & 4.4472 & 0 & 0.16219 & 96.5 \\
\hline No. 3. Condenser & 6.6310 & 5.4366 & 1.8040 & 2.9984 & 82.0 \\
\hline No. 4. Expansion system & 5.4366 & 4.9473 & 0 & 0.4893 & 91.0 \\
\hline No. 5. Evaporator & 1.8725 & 1.6665 & 0 & 0.206 & 89.0 \\
\hline
\end{tabular}

\section{E. Inefficiency analysis (anergy)}

The results of exergetic efficiency indicate that the highest rate of exergy destruction was located in the condenser equipment (Table 1). Consequentially, the partial inefficiencies of the five components were $11 \%, 3.5 \%, 18 \%, 9$ $\%$ and $11 \%$, respectively. The Grassman Engineering Diagram (Fig. 6) integrates the inefficiency analysis of each component and system, describing that the output variable, the exergy recovered or used, whose general efficiency is $69.7 \%$ or a high total inefficiency of $30.3 \%$. Comparing thermal irreversibilities, the condenser presented the greatest irreversibility İ or rate of exergy destruction (Fig. 7). 


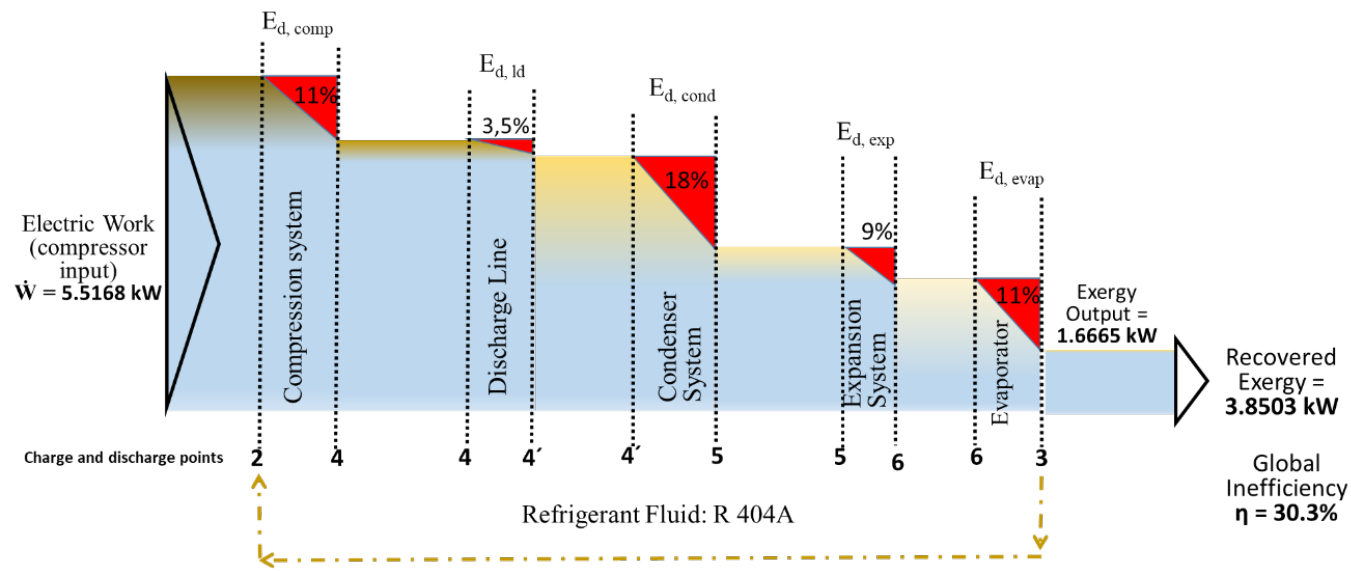

Fig. 6. Grassman diagram of system.

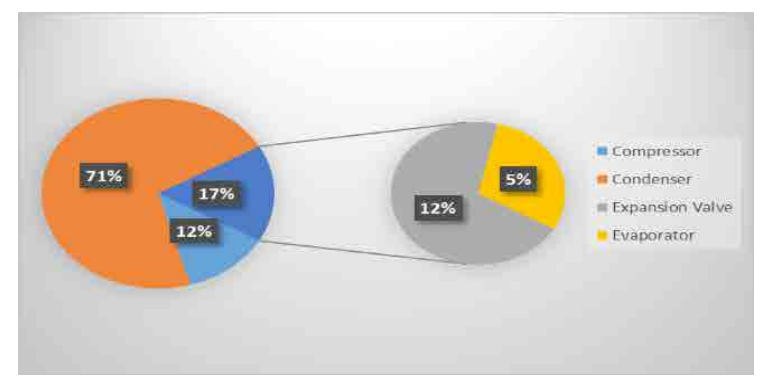

Fig. 7. Thermal irreversibilities compared by equipment.

\section{F. Cost analysis}

Table 2 shows a complementary tool to calculate exergetic by evaluating the exergetic operating costs and the exergoeconomic operating costs for equipment and currents (flows) of the refrigeration system. For the external electric motor, it is fulfilled that $\mathrm{k}_{\mathrm{F}}^{*}=\mathrm{k}_{1}^{*}$; for the compressor, that $\mathrm{k}_{\mathrm{F}}^{*}=\mathrm{k}_{2}^{*}$; for the condenser, that $\mathrm{k}_{\mathrm{F}}^{*}=\mathrm{k}_{4}^{*}$; for the expansion valve, that $\mathrm{k}_{\mathrm{F}}^{*}=\mathrm{k}_{5}^{*}$; and for the evaporator, that $\mathrm{k}_{\mathrm{F}}^{*}=\mathrm{k}_{8}^{*}$. The exergoeconomics costs (Table 2) correspond to the tariffs of electric power in México (April 2017) that was $\$ 1.7724 \mathrm{mx} / \mathrm{kW}-\mathrm{h}$, and the cost allocation of the exergetics costs.

\section{TABLE 2}

EQUIPMENT AND CURRENT COST BALANCES OF THE REFRIGERATION PROCESS

\begin{tabular}{|c|c|c|}
\hline Components & Exergetics costs (CEx) & Exergoeconomics costs \\
\hline Inlet to Electric Motor & $\mathrm{k}_{1}^{*}=1$ & $\mathrm{C}_{1}=1.7724 \$ \mathrm{mx}$ \\
\hline Electric Motor & $\mathrm{k}_{1}^{*} \dot{\mathrm{E}}_{1}=\mathrm{k}_{2}^{*} \dot{\mathrm{E}}_{2}$ & $\mathrm{C}_{1} \dot{\mathrm{E}}_{1}=\mathrm{C}_{2} \dot{\mathrm{E}}_{2}$ \\
\hline Compressor & $\mathrm{k}_{2}^{*} \dot{\mathrm{E}}_{2}=\mathrm{k}_{4}^{*} \dot{\mathrm{E}}_{4}-\mathrm{k}_{3}^{*} \dot{\mathrm{E}}_{3}$ & $\mathrm{C}_{2} \dot{\mathrm{E}}_{2}=\mathrm{C}_{4} \dot{\mathrm{E}}_{4}-\mathrm{C}_{3} \dot{\mathrm{E}}_{3}$ \\
\hline Condenser & $\mathrm{k}_{4}^{*} \dot{\mathrm{E}}_{4}=\mathrm{k}_{5}^{*} \dot{\mathrm{E}}_{5}+\mathrm{k}_{7}^{*} \dot{\mathrm{E}}_{7}$ & $\mathrm{C}_{4} \dot{\mathrm{E}}_{4}=\mathrm{C}_{5} \dot{\mathrm{E}}_{5}+\mathrm{C}_{7} \dot{\mathrm{E}}_{7}$ \\
\hline & $\mathrm{k}_{5}^{*}=\mathrm{k}_{7}^{*} 3^{\text {th }}$ consideration & $\mathrm{C}_{5}=\mathrm{C}_{7}$ \\
\hline Expansion system & $\mathrm{k}_{5}^{*} \dot{\mathrm{E}}_{5}=\mathrm{k}_{6}^{*} \dot{\mathrm{E}}_{6}$ & $\mathrm{C}_{5} \dot{\mathrm{E}}_{5}=\mathrm{C}_{6} \dot{\mathrm{E}}_{6}$ \\
\hline Evaporator & $\mathrm{k}_{8}^{*} \dot{\mathrm{E}}_{8}=\mathrm{k}_{6}^{*} \dot{\mathrm{E}}_{6}-\mathrm{k}_{3}^{*} \dot{\mathrm{E}}_{3}$ & $\mathrm{C}_{8} \dot{\mathrm{E}}_{8}=\mathrm{C}_{6} \dot{\mathrm{E}}_{6}-\mathrm{C}_{3} \dot{\mathrm{E}}_{3}$ \\
\hline Inlet to Evaporator & $\mathrm{k}_{8}^{*}=1$ & $\mathrm{C}_{8}=0$ \\
\hline
\end{tabular}


Tables 3 shows the costs obtained for currents, and Table 4 shows the operating costs, where exergetic and exergoeconomics costs are $\dot{\mathrm{E}}^{*}=\mathrm{k}^{*} \dot{\mathrm{E}} ; \Pi=\mathrm{c} \dot{\mathrm{E}} ; \mathrm{CE}_{\mathrm{X}}=\mathrm{k}_{\mathrm{F}}^{*} \dot{\mathrm{I}} ; \mathrm{CO}=\mathrm{C}_{\mathrm{F}} \dot{\mathrm{I}}$

TABLE 3

EXERGETICS AND EXERGOECONOMICS COSTS (CURRENTS)

\begin{tabular}{|c|c|c|c|c|}
\hline Current & $\dot{\mathrm{E}}(\mathrm{kW})$ & $\mathrm{k}^{*}$ & $\dot{\mathrm{E}}^{*}(\mathrm{~kW})$ & $\Pi(\$ \mathrm{mx} / \mathrm{h})$ \\
\hline 1 & 5.5168 & 1 & 5.5168 & 9.78 \\
\hline 2 & 4.6341 & 1.1905 & 5.5168 & 9.78 \\
\hline 3 & 2.5113 & 3.6275 & 9.1097 & 16.14 \\
\hline 4 & 6.6310 & 2.2058 & 14.6266 & 29.92 \\
\hline 5 & 5.4366 & 2.0201 & 10.9825 & 19.46 \\
\hline 6 & 4.9473 & 2.2198 & 11.0429 & 19.57 \\
\hline 7 & 1.8040 & 2.0201 & 3.6443 & 6.46 \\
\hline 8 & 1.8725 & 1 & 1.8725 & 3.32 \\
\hline
\end{tabular}

TABLE 4

EXERGETIC AND EXERGOECONOMIC-OPERATING COSTS

\begin{tabular}{|l|c|c|c|c|}
\hline \multicolumn{1}{|c|}{ Equipment } & $\dot{\mathrm{I}}(\mathrm{kW} / \mathrm{h})$ & $\eta(\%)$ & $\mathrm{k}_{\mathrm{F}}^{*}$ & CEX $(\mathrm{kW})$ \\
\hline No. 1. Electric Motor & 0.8827 & 84 & 0.8827 & 0,77915929 \\
\hline Fictitious: Discharge Line & 0.16219 & 96.5 & 2.2058 & 3,57758702 \\
\hline No. 2. Compressor & 0.5144 & 89 & 1.1905 & 6,123932 \\
\hline No. 3. Condenser & 2.9984 & 82 & 2.2058 & 66,1387072 \\
\hline No. 4. Expansion system & 0.4893 & 91 & 2.0201 & 9,8843493 \\
\hline No. 5. Evaporator & 0.206 & 89 & 1 & 0,206 \\
\hline
\end{tabular}

The measurement of exergoeconomic costs from the productive structure validates the calculations of rational efficiency. The highest operating costs are located in the condensation and expansion equipment, in points 4,5 and 6 of the thermal process.

\section{Conclusions}

In the productive structure of the studied slaughtering plant, the lowest exergetic efficiency was observed in the condenser ( $82 \%$ ), due to the lack of units coupled as ice banks, which is known to improve it. The high exergetic efficiency of the evaporator $(89 \%)$ shows a good performance in the restoration of exergy from steam. The inefficiency by exergetic work is greater, because to extract heat of the camera is a process of heat transfer by convection, against the dead state.

The rates of exergy destruction in the studied agroindustrial cold chain were higher during condensation, followed by compression, evaporation and expansion valve. These rates exceed by more than $15 \%$ those reported by the manufacturers of the equipment and components; furthermore, they differ from those reported in the literature because the parameters that affected the exergy were, in order, evaporation temperature, condensation temperature, sub-cooling temperature, and compressor pressure [13]. Kizilkan [14] analyzed the exergy in a refrigeration system designed with different freezing rates and R404A refrigerant, and found that the highest inefficiency rates were in the compressor, condenser, evaporator, and expansion valve.

Currently, the calculation of rational efficiency in agro-industrial processes with cold chain is based on information from the literature (thermotechnical) or from the manufacturer, and are based on energy calculations, which fail revealing hidden losses and costs in the process. Despite operating with technological levels above obsolescence, a considerable rational inefficiency was evidenced, since the average irreversibilities in the cold chain were estimated through exergetic balances in $17 \%$. However, manufacturers and camera assemblers report a safety factor, which only recognizes losses between 8-10\%. This imbalance implies that the manufacturer 
or designer oversized, in almost the double, the rational efficiency, when estimated by coefficients and parameters instead of exergetic evaluation of the system.

We validated the measurement using comparative methods of exergoeconomic efficiencies, thermodynamic diagrams, and revealing hidden costs that affect productivity. In conclusion, a real way to increase the productivity of a process is to intervene technically in the identification and reduction of inefficiencies.

\section{ACKNOWLedgements}

The authors acknowledge the Academic Body, Bioengineering, Biotechnology and Environmental Management, and the Research Group of Industrial Ecology at the University of Guanajuato. A special thanks to Drs. German Cuevas Rodríguez and Adorí Bernal Martínez from the University of Guanajuato. Thanks to the slaughter plant Rastro Frigorífico TIF 333 in León City (Mexico) and its Production Manager Carlos Muñoz S. M.V.Z. for the support during the insitu work.

\section{AUTHOR's CONTRIBUTIONS}

VHC was the author of the doctoral dissertation, from which the article is derived. As a Director, HCA oversaw the research, and critically reviewed the reports and the article. GCT supervised the work and industrial visit, discussed the results and fully contributed to the manuscript.

\section{REFERENCES}

[1] Y. Cengel, and M. Boles. Termodinámica. 7nd ed. México DF: Mc Graw-Hill, 2012.

[2] V.H. Cely, "Medición de la productividad en procesos que integren cadena de frío, basada en evaluaciones de exergoeconomía y ecoeficiencia," Ph.D. dissertation, Universidad Nacional de Colombia, Bogotá, D.C., 2017.

[3] A. Valero, and C. Torres, "Thermoeconomic Analysis," in Exergy, Energy System Analysis and
Optimization, Vol II. C.A. Frangopoulos Ed. Oxford: Eolss Publishers Co., chapter 1, pp.1-35, 2009.

[4] S. Kelly, "Energy system improvements based on endogenous and exogenous exergy destruction," Ph.D. dissertation, Technische Universitat Institute for Energy Engineering Germany, Berlin, 2008.

[5] I. Dincer, and M. Rosen, Exergy, Energy, Environment and Sustainable Development. Ontario, Canada: Elsevier Publication Books, 2007.

[6] J. Dewulf, et al. "Critical Review. Exergy: Its Potential and Limitations in Environmental Science and Technology," Environmental Science \& Technology, vol. 42 (7), pp. 2221-2232, Apr. 2008. DOI: http://doi.org/10.1021/es071719a.

[7] M. Suresh, K. Reddy, and A. Kolar A. "4-E: Energy, Exergy, Environment, and Economic, analysis of solar thermal aided coal-fired power plants," Energy for Sustainable Development, vol. 14 (4), pp. 267279, Dec. 2010. DOI: http://doi.org/10.1016/j. esd.2010.09.002.

[8] K. Manesh, et al., "Exergoeconomic and exergoenvironmental evaluation of the coupling of a gas fired steam power plant with a total site utility system," Energy Conversion and Management, vol. 77, pp. 469-483, Jan. 2014. DOI: http://doi. org/10.1016/j.enconman.2013.09.053.

[9] W. Kaminsky, "Refrigeration and the World Food Industry," Logistec, vol. 45, pp. 13-17, May. 2012.

[10] S. Kalaiselvam, and R. Saravan. "Exergy Analysis of scroll compressors working with R22, R407C, and R417A as refrigerant for HVAC system," Thermal Science, vol.13 (1), pp. 175-184, Jan. 2009. DOI: http://doi.org/10.2298/TSCI0901175K.

[11] D. Yu D, H. Van Paassen, and R. Siamak, "General modeling for model based FDD on building HVAC system," Simulation Practice and Theory, vol. 9 (6-8), pp. 387-397, May. 2002. DOI: http://doi. org/10.1016/S1569-190X(02)00062-X.

[12] R. Yin, Case Study Research Design \& Methods, 5nd. ed. Thousand Oaks, USA: Sage; 2014.

[13] J. Ahamed, R. Saidur, and H. Masjuki, "A review on exergy analysis of vapor compression refrigeration system," Renewable and Sustainable Energy Reviews, vol. 15 (3), pp. 1593-1600, Apr. 2011. DOI: http://doi.org/10.1016/j.rser.2010.11.039.

[14] Ö. Kizilkan, A. Kabul and A. Yakut. "Exergetic performance assessment of a variable speed R404A refrigeration system," International Journal of Energy Research, vol. 34 (6), pp. 463-475, May. 2010. DOI: http://doi.org/10.1002/er.1553. 
